\title{
The Outsized Costs of Investor-State Dispute Settlement
}

Lise Johnson, Columbia Center on Sustainable Investment, USA

Lisa Sachs, Columbia Center on Sustainable Investment, USA

The negotiation of SeVeral mega-treaties in 2015, including the Trans-Pacific Partnership (TPP), the Trans-Atlantic Trade and Investment Partnership (TTIP), the EU-Canada Comprehensive Economic and Trade Agreement (CETA), and other regional agreements, has generated substantial public discussion about the protections and privileges afforded to multinational enterprises through the investor-state dispute settlement (ISDS) mechanism in these treaties. ISDS has increasingly raised concerns among certain governments and civil society groups, particularly as a growing number of ISDS cases involve investors challenging a range of governmental measures taken in good faith and in the public interest, including measures related to environmental protection, public health and safety, and financial stability. Even representatives of international businesses - the purported beneficiaries of these texts - have voiced concerns about the costs of ISDS proceedings, uncertainty regarding outcomes of disputes, and an absence of rules to ensure the independence and impartiality of arbitrators.

The TPP negotiating parties deflected the underlying concerns about ISDS by assuring constituents that ISDS would be included in the TPP in an improved " $21^{\text {st }}$ century" form, resolving the controversial elements. When the text of the TPP was released in November 2015, it became evident that while the ISDS mechanism in the TPP includes some changes around the margins, its basic elements remain generally unchanged. Therefore, a cost-benefit analysis of ISDS remains essential. There are two fundamental questions: Is ISDS effective or necessary to produce its purported benefits? And do the potential benefits outweigh the costs? An analysis of ISDS as included in the TPP shows that the costs outweigh the alleged benefits, and alternative strategies should be employed to protect investors and promote the rule of law.

\section{Is ISDS Effective or Necessary to Produce Its Purported Benefits?}

ISDS is said to provide three core benefits: (1) increasing investment flows by providing potential investors additional security and protections, (2) depoliticizing investment disputes, and (3) improving the rule of law in the host state.

The first question is, therefore, is ISDS necessary or even effective in increasing investment flows and, if so, are these investments beneficial and to whom?
After roughly ten years of scholarly and practical inquiry with increasingly rigorous methodologies, there is no strong evidence that international investment agreements (IIAs), much less ISDS, impact investment flows. The various empirical studies examining trends in FDI flows establish no clear statistical relationship between signing a treaty and receiving increased investment (see, e.g., Berger et al, 2013; Sauvant \& Sachs, 2009). Similarly, a survey of in-house counsel in large US multinationals revealed that IIAs do not play any significant role in foreign investment decisions (Yackee, 2010). Some of the largest cross-border investment flows take place in the absence of treaties, including between the US and China, India, Brazil and the United Kingdom; in fact, Brazil, a major capital importer and exporter, has no treaties in force with ISDS, nor does it plan to include ISDS in its future agreements.

Importantly, even the basic presumption that increased investment flows of all types will necessarily lead to positive development outcomes in the host country is wrong, since the benefits depend on the details of each investment (such as the sector, technologies transferred, and jobs created, among other factors). Indeed, the Overseas Private Investment Corporation (OPIC), a US government entity which provides political risk insurance to foreign investors, recognizes that only certain types of investment create development benefits. OPIC therefore screens investments seeking coverage to ensure that at least a minimum development benefit is realized, and it prohibits support for projects that will result in harms in the host country.

Even less certain is the extent to which increased outward investment would generate benefits for the home country and its constituents. While outward investment could result in increased capital income and tax revenues at home, it can also result in outsourcing of jobs and tax structuring to decrease tax liabilities. Again, OPIC and other governmentprovided risk insurances recognize these potentially negative consequences and shape their insurance policies and decisions accordingly.

The TPP, like other treaties and the majority of tribunals interpreting those agreements, ignores the development impacts of investments that are afforded the benefits under the treaty, and it provides premium-free political risk insurance to investments irrespective of their development impacts or negative effects at home or abroad.

Second, proponents of ISDS argue that it is important for "depoliticizing" investment disputes, freeing host states from diplomatic pressure and the threat of "gunboat diplomacy" and home states from having to advocate on behalf of their domestic firms. In fact, whether a home 
state gets involved in an investor's dispute with its host state does not vary based on whether or not there is a treaty with ISDS in place; a recent study found no evidence that countries that have signed an investment treaty with the United States face any less diplomatic pressure in investment disputes (Jandhyala et al., 2015). Notably, the TPP does not prohibit home states from exercising diplomatic pressure before, during, or after an investment claim has been filed.

A third argument for ISDS is that this supra-national system strengthens the rule of law of treaty parties by reinforcing the importance of legal commitments. Yet, to the contrary, ISDS and investment treaties have been shown to weaken domestic rule of law (Ginsburg, 2005; see also Sattorova, 2014). The myriad reasons for this are elaborated below; the TPP, in its modifications, makes no attempt to correct for these failures.

Therefore, none of the purported core benefits of ISDS (increased investment flows, depoliticizing disputes, or improving the rule of law in host states) has been effectively realized by the inclusion of ISDS in investment treaties. Proponents of the system, including the investors and the lawyers and arbitrators who have an interest in the system's survival and growth, continue to tout these claims as the reason the mechanism is necessary, including in the TPP, but the empirical evidence continues to reveal that ISDS is neither effective nor necessary for achieving these benefits; indeed, these objectives can be realized through other means, as discussed below.

\section{Do the Purported Benefits of Investment Treaties Outweigh Their Costs?}

The second fundamental question is what ISDS costs host governments and their constituents, and whether the purported benefits outweigh the costs. These costs include negative impacts on (a) domestic law, policy, and institutions, and (b) costs of litigation, liability, and loss of regulatory space.

\section{Costs Related to Domestic Law, Policy, and Institutions}

Many ISDS claims are actually domestic law issues of administrative, contract, tort, or constitutional law that are merely removed from domestic legal institutions and processes and taken up in a parallel and specialized system available only to foreign investors, with fewer procedural barriers and greater substantive protections. A foreign investor seeking to challenge conduct of the US government, for example, can take a substantive or procedural due process action, a contract action, an action governed by the Administrative Procedures Act, or a tort claim against the government, and decide whether to bring it under domestic law or as a violation of a treaty's fair and equitable treatment (FET) provision - or both, in some cases. If the investor opts for ISDS instead of pursuing the domestic law claim, it can bypass all otherwise applicable procedural rules that may have complicated or frustrated its claim, including domestic rules of standing, statutes of limitation, requirements of exhaustion, doctrines of abstention, limits on judicial review, limits on available remedies, and rules regarding discovery, privilege, and evidence. Such domestic rules have been developed and refined over time and reflect important policy choices about the scope of public and private rights.

In addition to creating a parallel and preferential legal system for foreign investors, ISDS actually creates and protects new property rights at a cost to the broader public interest. In a growing number of cases, tribunals have created and restated a rule that specific representations or assurances given by government representatives can give rise to investors' "legitimate expectations," which are protected under the treaty's FET obligation from government interference. Tribunals have protected "legitimate expectations" even when the official who made the relevant commitment did not have actual authority to bind the government or when the commitment did not comply with necessary procedural requirements. While the TPP states that a breach of investors' "legitimate expectations" will not, standing alone, constitute a violation of the FET obligation, it suggests that investors' "legitimate expectations" can still be a factor considered by tribunals when determining whether a state has breached its FET obligations, effectively creating and protecting "rights" that would not be recognized under domestic law.

From the rule of law perspective, ISDS also upsets the separation and balance of powers. If domestic legislation sets the scope of administrative officials' ability to grant or define property rights, and administrative officials exceed that authority, a decision by a tribunal giving legal effect to the administrative officials' actions overrides legislative dictates. Moreover, many projects that trigger investor-state disputes are projects in which negative impacts are concentrated at the local level, but benefits (e.g., increased tax revenue) are realized at the national level. Through its protection of "legitimate expectations," ISDS allows investors to transform non-binding representations that favor their interests into rights protected under international law, weakening the voice and power of regulatory institutions and affected communities that might otherwise shape or constrain investors' proposed projects.

This parallel legal system also undermines the role of domestic institutions and courts in their core responsibilities of developing, interpreting, and applying the law. Particularly in common law jurisdictions where courts play a crucial role in shaping the substantive contours of the law over time, the ability of investors to sidestep domestic courts through recourse to ISDS effectively undercuts those domestic institutions'abilities to fulfill their important functions.

The closed nature of ISDS disputes further exacerbates the problems created by this parallel legal system. Despite the public importance of these cases, disputes under most existing and many new IIAs are still litigated and decided or settled behind closed doors. While the TPP requires significant transparency of ISDS proceedings, and authorizes (but does not require) ISDS tribunals to accept amicus curiae submissions from non-parties to the dispute, the interests and rights of non-parties can remain marginalized. Even if they will be affected by the treaty claims and outcomes, non-disputing parties have no legal rights to actually participate in the proceedings or shape the outcomes 
of the disputes. While domestic law often has a number of ways in which interested and affected individuals and entities are protected, including by requiring judicial oversight of settlements, allowing those affected to participate in proceedings, or requiring dismissal of claims when such individuals or entities cannot be joined, ISDS, in contrast, contains no such safeguards.

The system of providing special protections for investors is based on the presumption that foreign investors face bias and discrimination in domestic legal systems. In reality, these fears are overstated. Only eight of the more than 600 known ISDS cases have successfully alleged a violation of the national treatment obligation (protecting foreign investors against discrimination in favor of domestic investors) ${ }^{1}$; and in not one of them did the tribunal find that there was intentional nationality-based discrimination against the foreign investor. Rather, in those eight cases, liability was usually based on strategic protection of domestic producers that negatively affected the foreign investor claimant, measures that can be and have been challenged in inter-state trade dispute settlement mechanisms. In fact, studies show that foreign investors generally have greater power and influence over their host governments than domestic investors, particularly as governments around the world are competing for capital. The rational for establishing a privileged legal system for foreign investors is therefore based on an illusory threat. staggering sums, such as the $\$ 1.8$ billion award in Occidental v. Ecuador and the $\$ 50$ billion combined award in three closely related cases against Russia. While the TPP does contain some relatively new provisions regarding allocation of costs and compensation in awards, those changes do not result in any meaningful changes for states in terms of exposure to costs of litigation and liability.

While the costs that result from a loss of policy space are more difficult to assess and calculate, they are potentially even more damaging in their welfare effects. As Jonathan Bonnitcha's recent analysis of the economic impacts of investment treaties suggests (Bonnitcha, 2014), investment protection through ISDS can discourage economically efficient government regulation in the public interest.

\section{Moving Forward: What Are the Alternatives?}

Given that ISDS is not effective or necessary to achieve its intended benefits and that the costs are so substantial, its inclusion in treaties, including in the TPP, is unjustified. Yet if ISDS is removed from treaties, what recourse would foreign investors have for harm suffered due to host state conduct? Fortunately, there are other less costly and more appropriate mechanisms that can protect investor rights.

\section{(3) \\ Given that $Y S D S$ is not effective or necessary to acbieve its intended benefits ... its inclusion in treaties, including in the TPP. is unjustified}

The first place for recourse for foreign investors should remain the domestic law system of the host countries,

Thus, despite the assertion that ISDS strengthens the rule of law, the evidence is very much to the contrary. ISDS exacerbates inequality under the law by giving foreign investors access to a parallel and preferential legal system; diminishes the role of various government actors and institutions; and poses challenges to transparency and public participation. Moreover, to the extent that IIAs make it less risky for foreign investors to invest in jurisdictions with little respect for the rule of law, ISDS reduces incentives for governments to improve their investment climate, procedural fairness, domestic legal systems, and other aspects of the rule of law that would benefit domestic stakeholders as well. Overall, ISDS risks undermining rule of law objectives by upsetting and usurping the fundamental processes for developing, enforcing, and applying the law.

\section{Costs of Litigation, Liability, and Loss of Regulatory Space}

Finally, there are the actual costs of ISDS litigation and liability and those that result from the loss of policy space.

The costs of litigation and liability can be significant. Average costs of defending cases now approach $\$ 5$ million, and even victorious states often are left to bear those fees (see Hodgson, 2014). ISDS awards, estimated by some to be roughly $\$ 75$ million on average, ${ }^{2}$ can reach where all other domestic investors and stakeholders resolve their disputes. Debates around ISDS are premised on the false assumption that domestic systems are inadequate; in fact, many domestic legal systems do function well, particularly when exhaustion is required, giving governments the ability to correct lower level errors. In countries where legal systems and processes are weak, the focus of international agreements should be on strengthening those legal systems to ensure their robust development for all users, not undermining their development by creating a parallel process and set of rules for select foreign investors.

Second, investors can purchase additional protections through political risk insurance, which is designed to price political risk on the market, sending a signal to both the investors and the host states about the security of investments in the host jurisdictions. ${ }^{3}$ If a particular jurisdiction has a higher cost for political risk insurance, the host government will likely have the incentive to take steps to improve the investment climate for foreign investors, thereby strengthening rule of law incentives.

A third avenue is through existing human rights mechanisms such as regional mechanisms established in Europe (the European Court of Human Rights), the Americas (the Inter-American Commission and Court for the Protection of Human Rights), and Africa (the African Court and Commission on Human and People's Rights). ${ }^{4}$ These mecha- 
nisms are available to those aggrieved by government expropriations, discrimination, or denial of justice. To the extent that investors (or states) consider these mechanisms to be inadequate for resolving such claims, then as with inadequate domestic legal systems, the parties should take steps, through treaties and other collaborative means, to strengthen these human rights mechanisms for all stakeholders.

Fourth, as a last resort state parties may agree to treaty-based state-state dispute resolution mechanisms to resolve allegations of discriminatory or egregious treatment. There are plenty of precedents for robust, wellfunctioning state-state dispute resolution mechanisms including that of the World Trade Organization. ${ }^{5}$ Similar legal mechanisms can be used for resolution of investment disputes.

While it's laudable that the drafters of the major mega-treaties have recognized the need for reform of the traditional ISDS model, much more could and should have been done in the TPP to create alternatives to a fundamentally flawed system. The marginal changes that were made to ISDS in the TPP do not address the significant and justified concerns about that mechanism. The logic and evidence point to the need to drop ISDS altogether, and instead to strengthen and support national judicial processes and the rule of law, complemented, as necessary, through international human rights protections and stateto-state dispute resolution.

\section{References}

Berger, A., Busse, M., Nunnenkamp, P., \& Roy, M. 2013. Do trade and investment agreements lead to more FDI? Accounting for key provisions inside the Black Box. International Economics and Economic Policy, 10(2): 247-275.

Bonnitcha, J. 2014. Substantive Protections under Investment Treaties: A Legal and Economic Analysis. Cambridge: Cambridge University Press.

Ginsburg, T. 2005. International Substitutes for Domestic Institutions: Bilateral Investment Treaties and Governance. International Review of Law and Economics, 25(1): 107-123.

Hodgson, M. 2014. Costs in Investment-Treaty Arbitration: The Case for Reform. Transnational Dispute Management, 1.

Jandhyala, S., Gertz, G., \& Skovgaard Poulsen, L. N. 2015. Legalization and Diplomacy: Evidence from the Investment Regime. Paper presented at 2015 Annual Meeting of the American Political Science Association.

Sattorova, M. 2014. The Impact of Investment treaty Law on Host State Behavior: Some Doctrinal,Empirical, and Interdisciplinary Insights. In S. Lalani \& R. P. Lazo (Eds), The Role of the State in Investor-State Arbitration. Leiden: Nijhoff/Brill.

Sauvant, K., Sachs, L. (Eds) 2009. The Effect of Treaties on Foreign Direct Investments. New York: Oxford University Press.
Wagner, D. 2012. Managing Country Risk: A Practitioner's Guide to Effective Cross-Border Risk Analysis. New York: CRC Press.

Yackee, J. 2010. Do Bilateral Investment Treaties Promote Foreign Direct Investment? Some Hints from Alternative Evidence. Virginia Journal of International Law, 51: 397

\section{Endnotes}

1 This analysis is based on the information available through UNCTAD's Investment Dispute Settlement Navigator ("ISDS Navigator") as of December 14, 2015, and a review of the cases the ISDS Navigator lists as finding a national treatment violation. The ISDS Navigator is accessible at http://investmentpolicyhub.unctad.org/ISDS (updated as of September 1, 2015).

2 Estimates vary based on the datasets used, and the fact that many cases are not public. The figures above come from Hodgson (2014). They are based on data from cases with a public award as of December 31, 2012. They therefore do not include the $\$ 50$ billion Yukos awards.

3 Political risk insurance can be purchased from government and private entities. Government providers include entities established by individual home states (e.g., the US's OPIC) and entities established by multilateral institutions (e.g., the World Bank's Multilateral Investment Guarantee Agency). Private political risk insurance providers include Chartis, Lloyd's, Sovereign, and Zurich. See, e.g., Wagner(2012).

4 For an overview of these systems, see, e.g., http://www.ijrcenter.org/ courts-monitoring-bodies/.

5 For more information on the WTO's dispute settlement mechanism, see, e.g., https://www.wto.org/english/thewto_e/whatis_e/tif_e/disp1_e.htm.

Lise Johnson (Ijj2107@columbia.edu) is the Head of Investment Law and Policy at the Columbia Center on Sustainable Investment. She focuses on analyzing the contractual, legislative, and international legal frameworks that govern international investments, and that affect the positive and negative externalities generated by those investments. She received a Bachelor of Arts from Yale University, a Juris Doctor from University of Arizona, and a Masters in Law from Columbia University.

Lisa Sachs (Isachs1@law.columbia.edu) is the Director of the Columbia Center on Sustainable Investment, where she oversees the Center's three areas of focus: investments in extractive industries, investments in land and agriculture, and investment law and policy. She received a Bachelor of Arts in Economics from Harvard University, and earned her Juris Doctor and a Masters degree in International Affairs from Columbia University. 